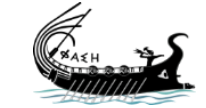

journal.phaselis.org
PHAS LLIS Issue V (2019)
Disiplinlerarası Akdeniz Araştırmaları Dergisi

Journal of Interdisciplinary Mediterranean Studies
The Re-Evaluation of a New Weight from Nicomedia

Nikomedia'dan Yeni Bir Ağırlığın Tekrar Değerlendirilmesi open 2 access journals

\author{
Hüseyin Sami ÖZTÜRK \\ (D) https://orcid.org/0000-0002-4366-1277
}

The entire contents of this journal, Phaselis: Journal of Interdisciplinary Mediterranean Studies, is open to users and it is an 'open access' journal. Users are able to read the full texts, to download, to copy, print and distribute without obtaining the permission of the editor and author(s). However, all references to the articles published in the e-journal Phaselis are to indicate through reference the source of the citation from this journal.

Phaselis: Journal of Interdisciplinary Mediterranean Studies is a peer-reviewed journal and the articles which have had their peer reviewing process completed will be published on the web-site (journal.phaselis.org) in the year of the journal's issue (e.g. Issue IV: JanuaryDecember 2018). At the end of December 2018 the year's issue is completed and Issue V: January-December 2019 will begin.

Responsibility for the articles published in this journal remains with the authors.

c) (i) (-) This work is licensed under a Creative Commons AttributionEY No SA Commercial-ShareAlike 4.0 International License.

Citation H. S. Öztürk, "The Re-Evaluation of a New Weight from Nicomedia". Phaselis V (2019) 251-256. http://dx.doi.org/10.18368/Pha.19016

Received Date: 28.09.2019 | Acceptance Date: 02.11.2019

Online Publication Date: 12.12.2019

Phaselis Research Project

www.phaselis.org 


\title{
The Re-Evaluation of a New Weight from Nicomedia
}

\author{
Nikomedia'dan Yeni Bir Ağırlığın Tekrar Değerlendirilmesi
}

\author{
Hüseyin Sami ÖZTÜRK *
}

\begin{abstract}
This paper introduces a new weight from Nicomedia in the Halûk Perk Museum Collection. It is not exactly known, where the weight dating to the reign of Emperor Philippus Arabs is from. Though according to Perk Collector, it must be from Sakarya. The inscription on side A of the pentagon-shaped weight dating to the $5^{\text {th }}$ regnal year of Emperor Philippus Arabs, gives the name and regnal year of Philippus Arabs and the name of L. Egnatius Victor Lollianus, the governor of Pontus et Bithynia; while the inscription on side B states the names of Titus Marcus Caesilius Aquila Cornelianus the logistes; and Marcus Ulpius Pius the Bithyniarkhes and agoranomos. The weight unit is not mentioned in the inscription.
\end{abstract}

Keywords: Philippus Arabs, L. Egnatius Victor Lollianus, Pontus et Bithynia, Nicomedia, Weight Inscription

Öz: Bu makalade Halûk Perk Müzesi Koleksiyonu'ndaki Nikomedeia'dan yeni bir ağırlık tanıtılmaktadır. Imparator Philippus Arabs zamanına tarihli bu ağılığın geliş yeri tam olarak bilinmemektedir. Bununla birlikte, Koleksiyoner Perk'in ifadesine göre, yazıt Sakarya'dan olmalıdır. Philippus Arabs'ın 5. yönetim yılına tarihlenen beşgen biçimli ağıllık, ağılığın A yüzündeki yazıt Imparator Philippus Arabs'ın adı ve yönetim yılı ile Pontus et Bithynia valisi L. Egnatius Victor Lollianus'un; B yüzündeki yazıt ise logistes Titus Marcus Caesilius Aquila Cornelianus'un; ve Bithyniarkhes and agoranomos Marcus Ulpius Pius adlarını vermektedir. Yazıtta ağırlık birimi verilmemiştir.

Anahtar sözcükler: Philippus Arabs, L. Egnatius Victor Lollianus, Pontus et Bithynia, Nikomedeia, Ağırlık Yazıtı

In 2018, we published an article about the mentioned weight found in Nicomedia, which belongs now to the Halûk Perk Museum ${ }^{1}$. However, after the inscription of the weight was published, our studies on this inscription have shown that some were published in a faulty manner. Therefore, the inscription is re-published here once again. So far, the published twenty-four lead weights attributed to Nicomedia are dated to the period beginning with $A D$ 113-114 to $273-274^{2}$. But a new unpublished weight from Halûk Perk Museum is dated to the $11^{\text {th }}$ regnal year of Domitian.

The weight made in the form of heptagonal with raised edges; pierced. According to Halûk Perk, it could be from Sakarya (Adapazarı). The weight is now at the Halûk Perk Museum (Env.

* Assoc. Prof. Dr., Marmara University, Faculty of Arts and Sciences, Department of History, İstanbul. hsoztrk@yahoo.com | D https://orcid.org/0000-0002-4366-1277

1 Öztürk 2018, 43-51.

2 Haensch - Weiß 2005, 443-498; Haensch - Weiß 2007, 183-218; Dönmez-Öztürk et alii 2008a, 243259; Dönmez-Öztürk et alii 2008b, 261-265; Haensch - Weiß 2014, 513-549 (= CPAI 2, Nr. 73; CPAl 3, 1, Nr. 413; 419). For Bithynian weights in general see SEG LV 1335; 1369-1388. 
No. HPM13442). Lead, $95 \times 110 \times 12 \mathrm{~mm}$; LH: 0.8-1.2 cm (A) - 0.7-1.3 cm (B).

Side A

ETOYC ETSN KY

$\mathrm{PI} \Omega$ N HM $\Omega$ N AYTOKP

ATOP $\Omega N$ M(APK $\Omega N) I O Y \wedge I \Omega N$ ФI

$\Lambda$ IחП $\Omega N$ CEBACT $\Omega N Y$

ПATEYONT[O]C THC EПAP

XEIAC $\wedge O Y(K I O Y)$ E! NAT(IOY) OYIKTO

POC $\triangle O \wedge \triangle I A N O Y$ ПPEC

BEYTOY KAI ANTICT

PATHГOY TSN

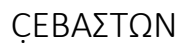

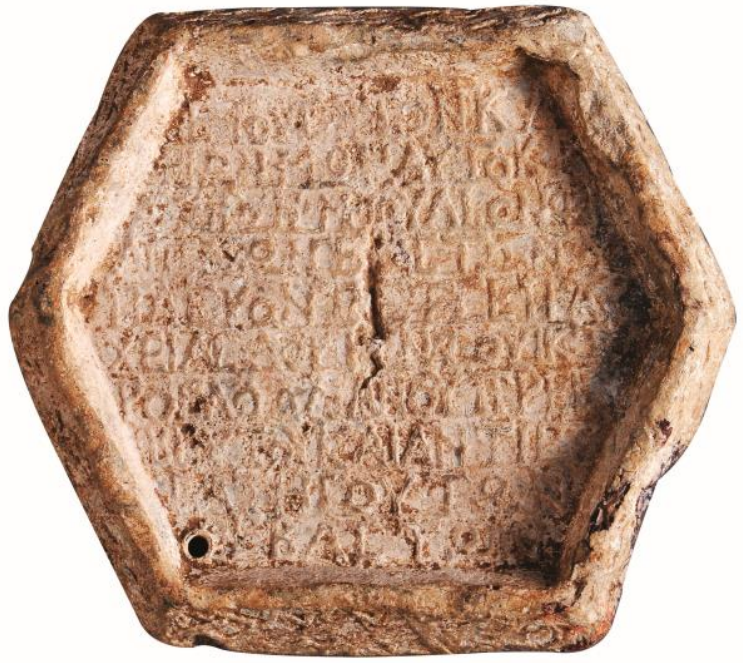

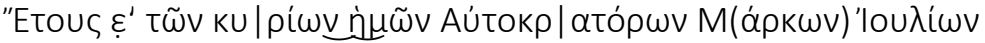

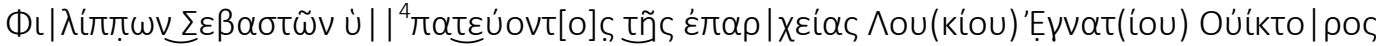

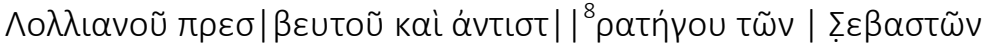

\section{Translation:}

In the $5^{\text {th }}$ year of our Lords and Emperors Marcus Iulius Philippus (and Marcus Iulius Philippus) Sebasti, during the tenure as provincial governor of Lucius Egnatius Victor Lollianus, the delegate and legatus of emperors,

\begin{tabular}{|c|}
\hline Side B \\
\hline КА $<$ < > МִОГІІСТЕY \\
\hline ONTOC TOY KPATI \\
\hline CTOY, TITIOY M(APKOY) KAI \\
\hline CIIIOY AKY^A KOP \\
\hline NHAIANOY AГOPANO \\
\hline MOYNTOC MAPKOY O \\
\hline ҮАПІОҮ ПІОҮ $\triangle$ \\
\hline HMHTPIANOY B \\
\hline EIOYNIAPXOY \\
\hline
\end{tabular}

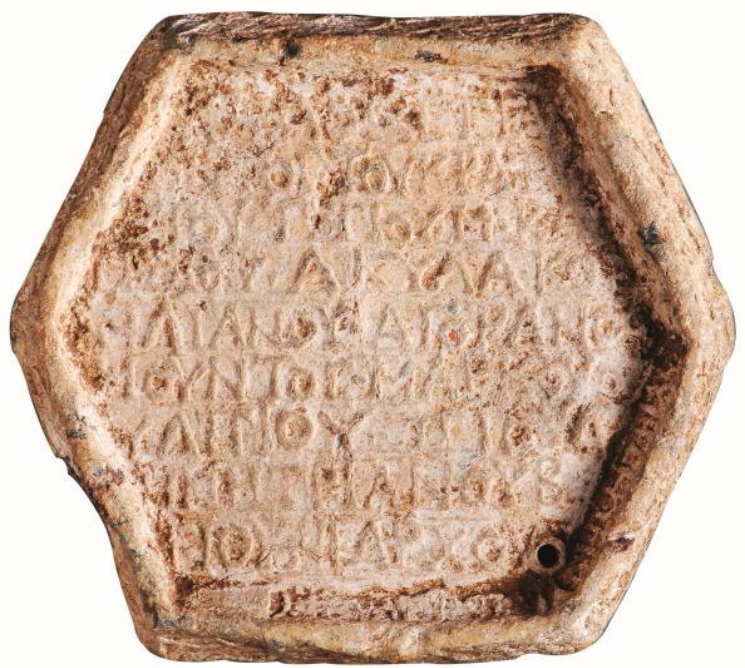

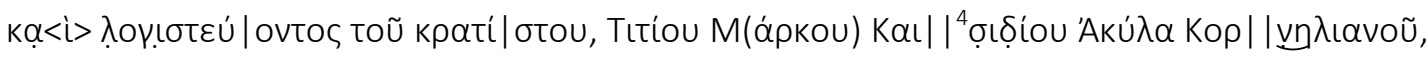

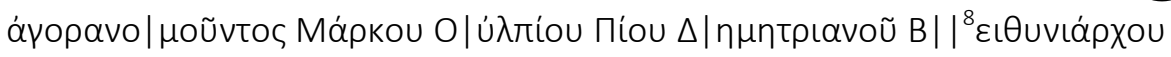

\section{Translation:}

and (during the time of) logistes, vir egregius Titius Marcus Caedilius Aquila Cornelianus (and) agoranomos Marcus Ulpius Pius Demetrianus (and) Bithyniarkhes. 
[Control stamp]

M(АРКOY) OY^ПIOY ПIOY

$\triangle$ HMHTPIANOY

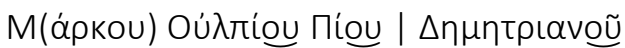

Translation:

Marcus Ulpius Pius Demetrianus' (control stamp).

The inscription on side A of weight dating to the $5^{\text {th }}$ regnal year of Emperor Philippus Arabs, gives the name and regnal year of Philippus Arabs and the name of L. Egnatius Victor Lollianus, the governor of Pontus et Bithynia; while the inscription on side B states the names of Titus Marcus Caesilius Aquila Cornelianus, logistes of Nicomedia; Marcus Ulpius Pius, the Bithyniarkhes and agoranomos of the city of Nicomedia.

The name and regnal year of Philippus Arabs is mentioned on side A. A similar statement is known on another weight dating to the reign of Philippus Arabs $^{3}$. This statement in the inscription proves that Philippus lunior had the title Augustus and began to rule jointly with his father; as Philippus Iunior was made Augustus in July or August AD $247^{4}$.

It is known from two published weight inscriptions that L. Egnatius Victor Lollianus was legatus Augusti pro praetore in Pontus et Bithynia during the reign of Decius ${ }^{5}$. In those two inscriptions, the first regnal year of Decius, i.e. AD 249. With this new weight with the inscription " 5 th regnal year of Philippus Arabs", it can be seen that L. Egnatius Victor Lollianus was working in Pontus et Bithynia since AD 247. In the governors list that was published in 2014 by R. Haensch and P. Weiß, who works on governors of Pontus et Bithynia for a long time, the dates of L. Egnatius Victor Lollianus' tenure are shown as 23.IX.247-22.IX.248. The later occupant of the post is C. Sabucius Secundus Paulus Modestus, whose tenure was - according to Haensch and Weiß - 23.IX.250-c. June 250. Apparently Lucius Egnatius Victor had stayed in Pontus et Bithynia province for two years. This situation can be explained with the conflict between Philippus Arabs and Decius.

From the inscription on side B, we learn that there was a logistes (the equivalent of Latin curator rei publicae ${ }^{7}$ ) of named Titius Marcus Caesilius Aquila Cornelianus. There are also the names of previously unknown Titius Marcus Caesilius Aquila Cornelianus. Only nine of these lead weights bear the title of logistes and the names of these logistai were written with the governor and agoranomos on the same weight. It is known that Nicomedia has produced a whole series of weights referring to its logistai, which date from about the mid-second to midthird century. Up to now, only three governors recorded in the whole series of Pontus et Bithynia seems to have been as curator rei publicae. In generally, logistes being official of the central government in the provincial city were selected from equestrian order and usually held

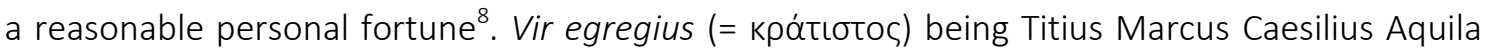

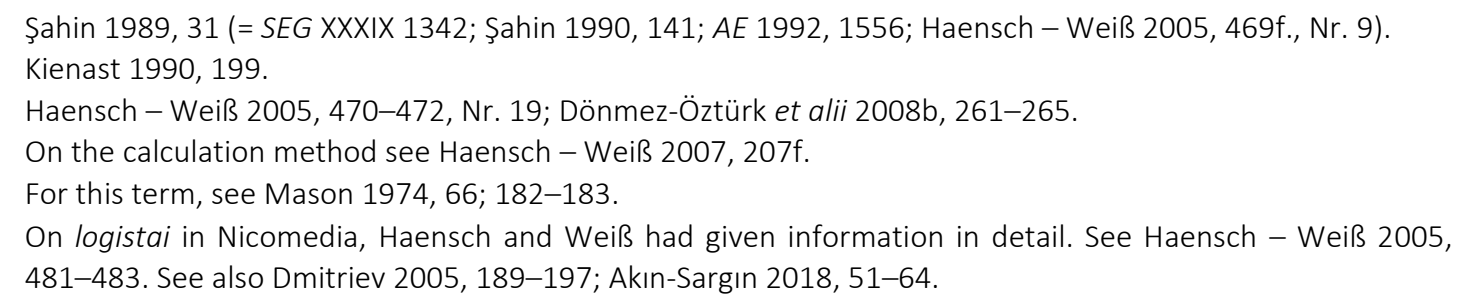


Cornelianus was appointed by Philippus Arabs. This title was first used as a general term for the members of the ordo equester under Marcus Aurelius. Licinius recognizes four grades of equestrian rank: Perfectissimus vir, ducenarius vir, centenarius vir and egregius vir ${ }^{9}$. As can be seen, egregius (= кра́tıбтоৎ) is at the lowest level of the hierarchy. These titles were only achieved by some members of the equestrian class who completed their duties as officers in the army ${ }^{10}$.

Again from the inscription on side B, we learn that there was a Bithyniarkhes and agoranomos Marcus Ulpius Pius Demetrianus from Nicomedia. The praenomen Marcus and nomen gentile Ulpius of agoranomos M. Ulpius Pius Demetrianus show that the ancestors of Pius may have been obtained the right of citizenship during the reign of Emperor Traianus. The lead weights attributed to Nicomedia published recently carry about twenty-tree agoranomoi of Nicomedia ${ }^{11}$. The most of these agoranomoi mentioned on these weights obtained Roman citizenship. Only two people mentioned in these weights do not have Roman citizenship. These people must be members of the leading families of Nicomedia. Moreover, three more agoranomoi from Nicomedia are known from inscriptions in TAM IV 37, 42, 43.

As it is known, the Bithyniarkhes was a prominent person of the province as the supreme officer of the koinon and Marcus Ulpius Pius Demetrianus must have been one of them. There are several arguments about Bithyniarkhes ${ }^{12}$. After the imperial cult was established in 29 BC, one of its most conspicuous figures became arkhiereus. We find after a while that arkhiereus is with Bithyniarkhes in the same inscriptions or alone. So Bithyniarkhes is considered by Fernoux ${ }^{13}$ as the presiding official of the Bithynian koinon. Besides, a Bithyniarkhes list is given by Fernoux ${ }^{14}$. According to Madsen, Bithyniarkhes was not only different from but also superior to that of arkhiereus $^{15}$. It is known that some of Bithyniarkhes were ex-logistai. Hence, they may have originated from the equestrian class, though equestrian status was not a prerequisite for becoming a Bithyniarkhes ${ }^{16}$.

13 Fernoux 2004, 353

14 Fernoux 2004, 350-352.

15 Madsen 2009, 93.

16 Bekker-Nielsen 2008, 105. 


\section{BIBLIOGRAPHY}

$A C M$

$A E$

Akın-Sargın 2018

Alföldy 1986

Bekker-Nielsen 2008

Chiron

Cod. Theod

CPAI 2

CPA/ 3,1

Dmitriev 2005

DNP Der neue Pauly.

Acta Classica Mediterranea.

L'Année épigraphique.

Y. Akın-Sargın, "Yazıtlar Işığında Roma İmparatorluk Dönemi Lykia, Pamphylia ve Pisidia'da curator rei publicae Olgusu". Eds. O. Tekin - T. Kahya - A. Özdizbay - Nihal Öner-Tünen - M. Wilson, Uluslararası Genç Bilimciler Buluşması II: Anadolu Akdenizi Sempozyumu 04-07 Kasım 2015, Antalya: Sempozyum Bildirileri. (2018) 51-64 [e-ISBN 978-605-2116-52-4].

G. Alföldy, Die römische Gesellschaft, Stuttgart 1986.

T. Bekker-Nielsen, Urban Life and Local Politics in Roman Bithynia: The Small World of Dion Chrysostomos. Aarhus 2008.

Chiron: Mitteilungen der Kommission für Alte Geschichte und Epigraphik des Deutschen Archäologischen Instituts.

Codex Theodosianus = Theodosiani libri XVI, I-II, Hrsgg. von Th. Mommsen - P. M. Meyer, Berlin 1954².

O. Tekin - G. Baran-Çelik, Corpus Ponderum Antiquorum et Islamicorum, Turkey 2: Greek, Roman, Byzantine and Islamic Weights in the Department of Metal Objects. İstanbul 2013.

O. Tekin, Corpus Ponderum Antiquorum et Islamicorum, Turkey 3: Suna and Inan Kiraç Foundation Collection at the Pera Museum, Part 1: Greek and Roman Weights, İstanbul 2013.

S. Dmitriev, City Government in Hellenistic and Roman Asia Minor. Oxford 2005.

F. Dönmez-Öztürk - R. Haensch - H. S. Öztürk - P. Weiß, Aus dem Pera Museum (Istanbul): Weitere Gewichte mit Nennung von Statthaltern von Pontus et Bithynia", Chiron 38 (2008) 243-259.

Dönmez-Öztürk et al.2008b F. Dönmez-Öztürk - R. Haensch - H. S. Öztürk - P. Weiß, “Aus dem Halûk Perk Museum (İstanbul): Ein weiteres Gewicht mit Nennung eines Statthalters von Pontus et Bithynia". Chiron 38 (2008) 261-265.

$E A$

Eck 1998

Fernoux 2004

Giannakopoulos 2016

Haensch - Weiß 2005

Haensch - Weiß 2007

Haensch - Weiß 2014

Kienast 1990

Madsen 2009

Meyer 1961

Öztürk 2018
Epigraphica Anatolica.

W. Eck, Verwaltung des römischen Reiches. Vol. II. Basel - Berlin 1998.

H.-L. Fernoux, Notables et elites des cités de Bithynie aux époques hellénistique et romaine (IIle siècle av. J.-C. - Ille siècle ap. J.-C.): Essai d'histoire sociale. Lyon 2004.

N. Giannakopoulos, "Groups and Associations in Bithynia and Pontus: Interaction with Prominent Statesmen and Provincial Governors". Eds. E. N. Akdoğu-Arca - N. Gökalp-Özdil - B. Takmer, (Eds.), Vir doctus Anatolicus: Studies in memory of Sencer Şahin. İstanbul (2016) 364-387.

R. Haensch - P. Weiß, "Gewichte mit Nennung von Statthaltern von Pontus et Bithynia", Chiron 35, 443-498.

R. Haensch - P. Weiß, "<Statthaltergewichte> aus Pontus et Bithynia. Neue Exemplare und neue Erkenntnisse", Chiron 35 (2007) 183-218.

R. Haensch - P. Weiß, "Weitere <Statthaltergewichte> von Nikomedeia: Neue Ergebnisse zur Stadt- und Reichsgeschichte", Chiron 44 (2014) 513-549.

D. Kienast, Römische Kaisertabelle: Grundzüge einer römischen Kaiserchronologie: Wissenschaftliche Buchgesellschaft. Darmstadt 1990.

J. M. Madsen, Eager to be Roman: Greek response to Roman Rule in Pontus and Bithynia, London.

E. Meyer, Römischer Staat und Staatsgedanke, Darmstadt.

H. S. Öztürk, "A New Date for L. Egnatius Victor Lollianus' Governorship in the Province of Pontus et Bithynia". ACM I (2018) 43-51.

Supplementum Epigraphicum Graecum. 
Strothmaan 2002

Şahin 1989

Şahin 1990

TAM IV(1)
M. Strothmaan, "Vir egregius". DNP 12/2 (2002) 241.

S. Şahin, "Ein Bleigewicht aus Nikomedeia unter Kaiser Philippus und seinem Statthalter M. Aurelius Artemidorus". Ed. C. Bayburtluoğlu, Akurgal'a Armağan - Festschrift Akurgal. Ankara (1989) 309-316.

S. Şahin, "Ein Bleigewicht aus Nikomedeia unter Kaiser Philippus und seinem Statthalter M. Aurelius Artemidorus", EA 16, (1990) 139-146.

F. K. Dörner (Ed.), with the assistance of M.-B. von Stritzky, Tituli Asiae Minoris, IV: Tituli Bithyniae linguis Graeca et Latina conscripti, 1. Paeninsula Bithynica praeter Chalcedonem. Nicomedia et ager Nicomedensis cum septentrionali meridianoque litore sinus Astaceni et cum lacu Sumonensi. Vienna 1978. 